\title{
Dixonville kimberlites, Pennsylvania, USA: Indicator mineralogy and thermobarometry
}

\author{
B. C. Hearn, Jr. ${ }^{1}$ and D. J. Schulze ${ }^{2}$ \\ ${ }^{1}$ U.S. Geological Survey, Reston, VA, USA \\ ${ }^{2}$ University of Toronto, Mississauga, ON, Canada
}

The Dixonville (Tanoma) kimberlites in west-central Pennsylvania occur in a narrow east-west-trending zone, at least $3 \mathrm{~km}$ long, of sub-parallel dikes that have been encountered in underground coal mines. The kimberlites contain abundant megacrysts of olivine, ilmenite, and phlogopite, and less abundant garnet and clinopyroxene. Although the dikes have no known surface outcrops, panned concentrates from several drainages above the mines contain kimberlitic indicator minerals: ilmenite, garnet, clinopyroxene, orthopyroxene, and olivine (analysed size range for most is $0.25-2 \mathrm{~mm}$, and up to $7 \mathrm{~mm}$ for ilmenites).

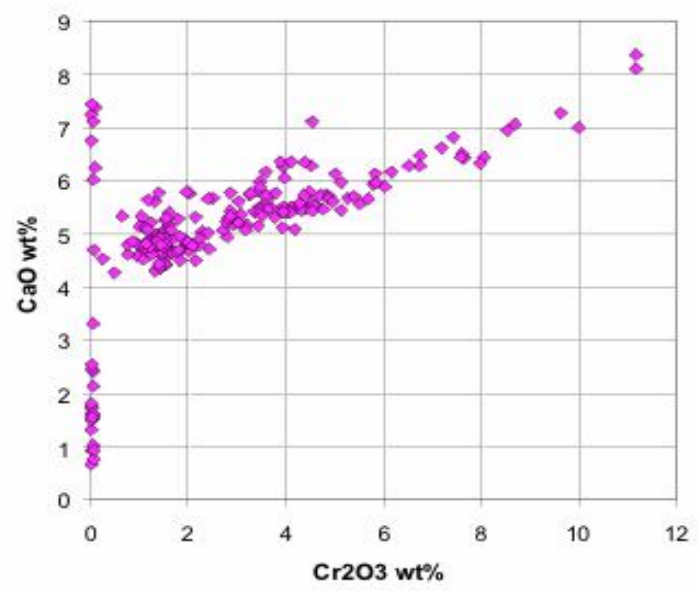

Fig. 1 Garnets from panned concentrates of stream sediments in drainages crossing Dixonville kimberlite dikes.

The only reported deep-source xenoliths are glimmerites. However, the presence of garnet peridotites, either as discrete xenoliths or as disaggregated mineral assemblages, is indicated by lherzolitic G9 purple or pink Cr pyropes that contain up to 11.2 wt\% $\mathrm{Cr} 2 \mathrm{O} 3$, with two ranges of $\mathrm{TiO} 2$ content, 0-0.2 and 0.3-0.7 wt\%. Harzburgitic G10 high-Cr, low-Ca garnets are absent. Megacryst garnets are represented by orange to red-orange fragments, containing 0.4-0.9 wt\% $\mathrm{TiO} 2$ and less than $2 \mathrm{wt} \%$ Cr2O3. Garnets with 1-2 wt\% Cr2O3 and less than 0.25 wt $\% \mathrm{TiO} 2$ may be from low-Cr garnet lherzolites or from garnet pyroxenites. Eclogites are absent, based on the lack of jadeitic clinopyroxenes or garnets with $\mathrm{Na} 2 \mathrm{O}>0.08$ wt $\%$. Pink to orange almandine-rich garnets are crustal.

Ilmenites contain 1-4 wt\% Cr2O3 and 8-14 wt\% $\mathrm{MgO}$ (right limb of the $\mathrm{MgO}-\mathrm{Cr} 2 \mathrm{O} 3$ "parabola"). Rims are enriched in $\mathrm{MgO}$, with almost constant $\mathrm{Cr} 2 \mathrm{O} 3$. Nb2O5 contents are $0.14-0.53 \mathrm{wt} \%$.

Clinopyroxenes contain relatively low $\mathrm{Cr} 2 \mathrm{O} 3$, up to 1 wt \%. Their A12O3-MgO contents show derivation from both garnet peridotites and garnet-free, spinel peridotites. However, spinels are very sparse in pan concentrates.

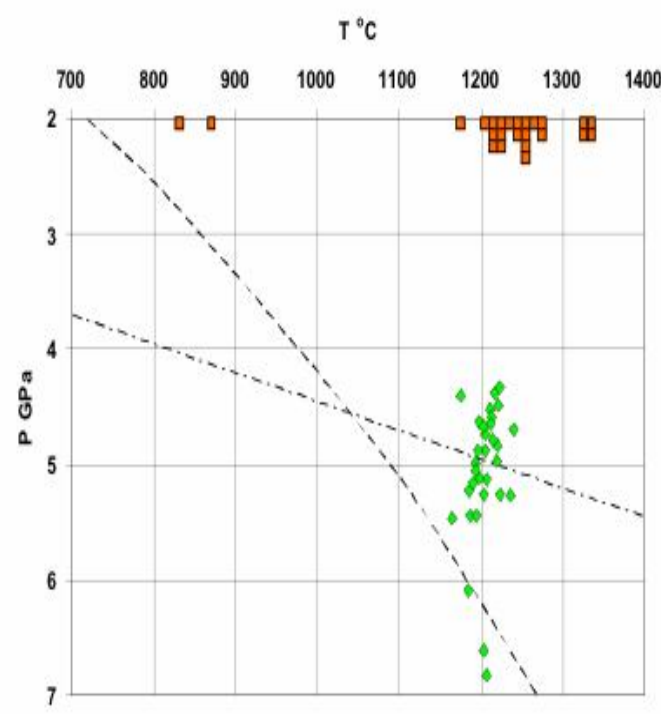

Fig. 2 Clinopyroxene xenocryst temperatures $\left({ }^{\circ} \mathrm{C}\right)$ and pressures (Gpa) (diamond symbols) calculated by the Nimis and Taylor (2000) method. Orthopyroxene xenocryst temperatures (square symbols) calculated from the Lindsley and Dixon (1976) solvus. Dashed line, $38 \mathrm{~mW} / \mathrm{m}^{2}$ shield geotherm; dot-dash line, diamond - graphite stability boundary.

Calculated temperatures and pressures by the NimisTaylor method for $\mathrm{Cr}$ diopsides of garnet peridotite affinity show an array with $\mathrm{T}=1160-1230$ degrees $\mathrm{C}$ 
and $\mathrm{P}=4.3-5.4 \mathrm{GPa}$ (with 3 outliers in the 6.0-6.8 $\mathrm{GPa}$ range). Calculated temperatures for orthopyroxene xenocrysts, from the Lindsley and Dixon (1976) solvus, show a slightly higher range, 1180-1230 degrees C. The clinopyroxene array is above a continental geotherm, and crosses the diamondgraphite stability boundary. These temperaturepressure values indicate heating of the upper mantle in a depth range of 135 to $175 \mathrm{~km}$ beneath Proterozoic, Grenville-age basement. Lack of diamond potential is indicated by the chemistry of the indicator minerals, and by the young cratonic age setting.

\section{References}

Lindsley, D.A., Dixon, S.A., 1976. Diopside-enstatite equilibria at $850^{\circ}$ to $1400^{\circ} \mathrm{C}, 5$ to $35 \mathrm{~kb}$. American Journal of Science 276, 1285-1301.

Nimis, P., Taylor, W.R., 2000. Single clinopyroxene thermobarometry for garnet peridotites: Part I. Calibration and testing of a Cr-in-Cpx barometer and an enstatite-in-Cpx thermometer. Contributions to Mineralogy and Petrology 139, 541-554. 